\title{
アングルをせん断伝達要素とし て用いる耐震補強工法の開発
}

\section{DEVELOPMENT OF STRENGTHENING METHODS USING ANGLES AS SHEAR-KEYS}

\author{
松浦恒久——1 \\ 牧田敏郎—— $* 3$ \\ 岩川浩二

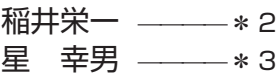 \\ キーワード \\ 耐震補強，接合部，アングル，シアキー
}

Keywords:

Seismic strengthening, Joint, Angle, Shear-key

\section{1.はじめに}

既存鉄筋コンクリート造建物における耐震補強工事では, 一般的 に鉄筋コンクリート増設壁補強工法または枠付き鉄骨ブレース補強 工法が採用されている。これらの在来工法では，既存躯体と耐震要 素との接合は，あと施工アンカーを用いた間接接合形式が用いられ ている。あと施工アンカーの施工時には，騒音，振動が発生し，建 物を使用しながらの耐震補強工事では大きな問題となっている。こ れらの問題を解決する手段として, 接着剤により而震要素を既存躯 体に取り付ける直接接合工法 ${ }^{1)}$ ，鋼管をコッターとして用いる工法 2)などが開発されている。

本工法は，間接接合工法におけるあと施工アンカーの施工時，お よび目荒らし時に発生する騒音, 振動の低減を図る目的で開発した 耐震補強工法で，問題の解決を直接接合工法ではなくあくまでも間 接接合工法の改良により行ったものである。

工法の概要を図 1 に示寸。本工法は, 鉄筋コンクリート造 (以下, $\mathrm{RC}$ 造）および鉄骨鉄筋コンクリート造（以下， SRC 造）の既存建築 物の既存躯体と鉄筋コンクリート増設壁または枠付き鉄骨ブレース などの増設部との間接接合部のせん断伝達要素（シアキー）として アングルを用いるものである。なお，既存躯体の目荒らしは行わな い。アングルは既存の柱, 梁のかぶりコンクリート部分に彫り込ん だ溝にエポキシ樹脂接着剤により固定し，他端部を増設部材側に定 着させることにより，あと施工アンカーと同様にシアキーとしての 機能を持たせるものである。騒音, 振動の発生を低減する以外に, (1)アングル取り付け用の溝の深さは，かぶり厚さ程度としているた め，柱，梁主筋を傷付けることがない。加えて SRC 造における内蔵
Tsunehisa MATSUURA $-* 1$
Toshirou MAKITA- $* 3$
Koji IWAKAWA $* 4$

In seismic retrofitting of existing $\mathrm{R} / \mathrm{C}$ buildings, indirect connection by post-installed anchors is used for the load transfer mechanism between existing building frames and steel braces or extension $\mathrm{R} / \mathrm{C}$ walls. A new seismic strengthening method was developed using angles as shearkeys.

In the indirect connection between the structural frame of existing buildings and earthquake resistance elements, shear force is carried by angles as shear-keys. Seismic performance of the frame strengthened by angles as shear-keys in the indirect connection was investigated experimentally. Based on the experimental results, the developed method was verified to be efficient for strengthening existing building frames.

鉄骨にアングルが干渉することもない。(2)使用する工具は軽量で， 乾式方式の電動工具であるため施工性が良い。というような特長を 有している。

本工法の施工手順を図 2 に示す。在来工法の施工は振動ドリルで 躯体に孔をあけ，あと施工アンカーを孔に固定し，スパイラル筋を 配置した後, 間接接合部にコンクリートまたは無収縮モルタルを充 填するものである。これに対して, 本工法ではまず電動カッタによ り, 既存の柱, 梁のかぶりコンクリート部分に溝を彫り込む。彫り 込んだ溝にアングルを挿入し，エポキシ樹脂接着剤で固定するもの である。以降は，在来工法と同様に間接接合部にコンクリートまた は無収縮モルタルを充填するものである。

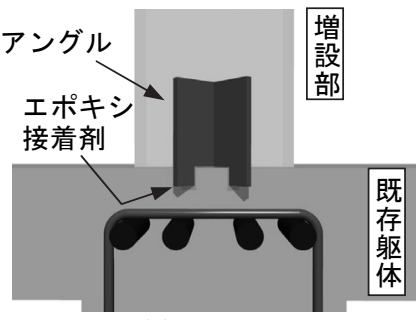

(a) 本工法

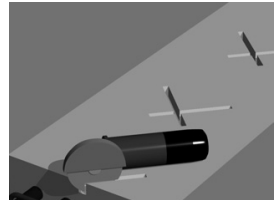

(a) 溝の掘込み
図 1 工法比較

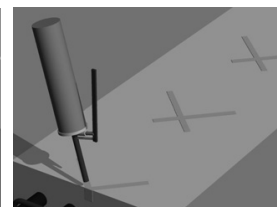

(b) 接着剂注入

図 2 施工手順

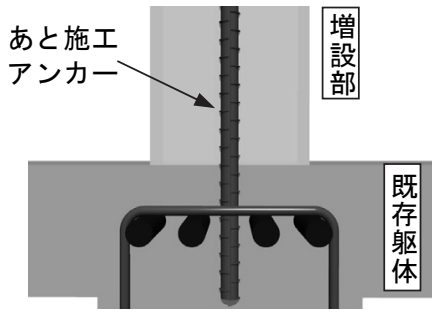

（a）従来工法

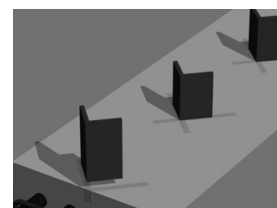

(c)アングル取り付け

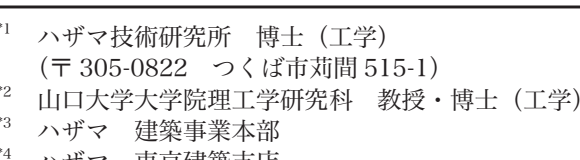

Technical Research Institute, HAZAMA Corporation, Dr. Eng.

Prof., Graduate School of Science and Eng., Yamaguchi Univ., Dr. Eng. Architectural Management Div., HAZAMA Corporation

Tokyo Architectural Construction Branch, HAZAMA Corporation 


\section{2. 使用工具の騒音および振動の測定}

本工法およびあと施工アンカーの施工で使用される各種工具に より発生する騒音, 振動を把握し, 本工法による騒音, 振動の低減 効果を明確にすることを目的として実建物における騒音, 振動を測 定した。

作業位置と測定点を図 3 に示す。建物はR C 造 4 階建ての事務所 ビルで, 作業場所を 4 階として 2 階〜 4 階で騒音, 振動の測定を行 った。図 4 および図 5 は各種工具による 4 階と 3 階での音圧レベル と振動加速度レベルを実測した結果である。なお，図中の dBA は A 特性周波数重み付けを行った騒音レベルを表し, 振動レベルは実測 した振動加速度レベルを振動感覚補正特性によって人間の感じ方を 加味して補正した值を示す。

図 4 (a)に示すように作業階である 4 階の発生騒音は各工具とも 高周波数ほど大きいレベルを示し, 最大值は電動カッタで $96 \mathrm{~dB}$, 振 動ドリルで 96dBA，低騒音型ドリルは 83dBA と，低騒音型ドリルの 発生騷音が最も小さい。図 5 に示すように発生振動は電動カッタで 67. $9 \mathrm{~dB}$ ，振動ドリルで $81.2 \mathrm{~dB}$ ，低騷音型ドリルは $59.7 \mathrm{~dB}$ であり， 電動カッタの発生振動は振動ドリルより $10 \mathrm{~dB}$ 程度小さくなってい る。電動カッタの発生振動は低騒音型ドリルと同程度であるが，工 具自体から発生する騒音が大きいため, 発生騒音は振動ドリルと同 程度となっている。

図 4 (b) に示寸 3 階での発生騒音は振動ドリルが大きく, 騒音レ ベルは $68 \mathrm{dBA}$ で，電動カッタと低騒音型ドリルの発生騒音は 48dBA 程度で, 振動ドリルよりも $20 \mathrm{dBA}$ 程度小さい数值である。図 5 に示 すように発生振動は電動カッタで $26.7 \mathrm{~dB}$, 振動ドリルで $32.9 \mathrm{~dB}$, 低 騒音型ドリルは $28.6 \mathrm{~dB}$ と, 電動カッタの発生振動は振動ドリルより も $6 \mathrm{~dB}$ 程度小さくなっている。

各種工具により発生する騷音，振動測定の結果，本工法で用いる 工具はあと施工アンカーの施工に用いられる振動ドリルに比べて, 騷音，振動の発生を低減できることが確認できた。

\section{3. 構造性能確認実験}

本工法の構造性能を検討するために，接合部の要素実験 ${ }^{3)}$ および 補強架構の加力実験を実施した。

\section{1 接合部の要素実験 ${ }^{3)}$}

間接接合部の基本的な性能を確認するために間接接合部のみを 取り出した要素実験を行った。代表的な試験体形状を図 6 に示寸。 試験体は 2 面せん断型で, 縮尺が約 $1 / 1.4$ となる縮小試験体および 実大スケールとし，アングルの埋め込み深さ，アングル間隔，アン グルの向き，アングルとあと施工アンカーの併用および既存躯体の 構造形式を実験要因とした 36 体とした。加力は全て, 万能試験機に より中央部分に荷重を作用させる押し抜き型の加力とした。

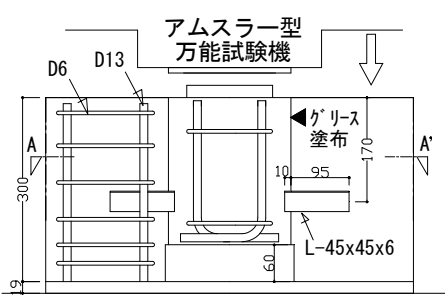

既存躯体部

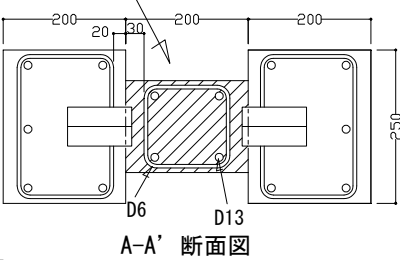

図 6 試験体形状および加力方法

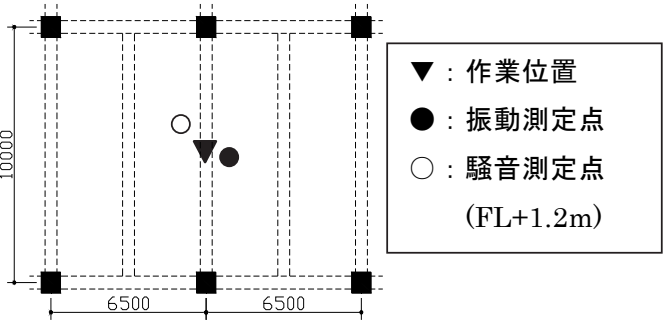

図 3 作業位置と測定点
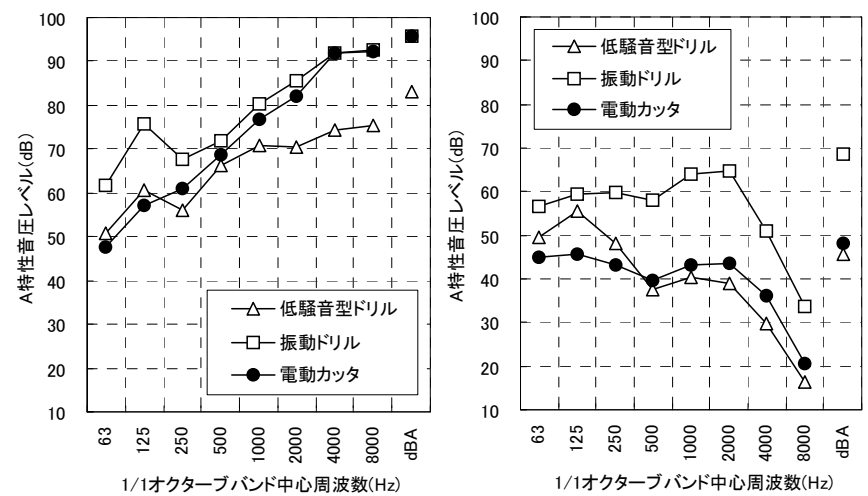

(a) 4 階（作業位置

(b) 3 階（執務室）

図 4 各種工具の騒音測定結果
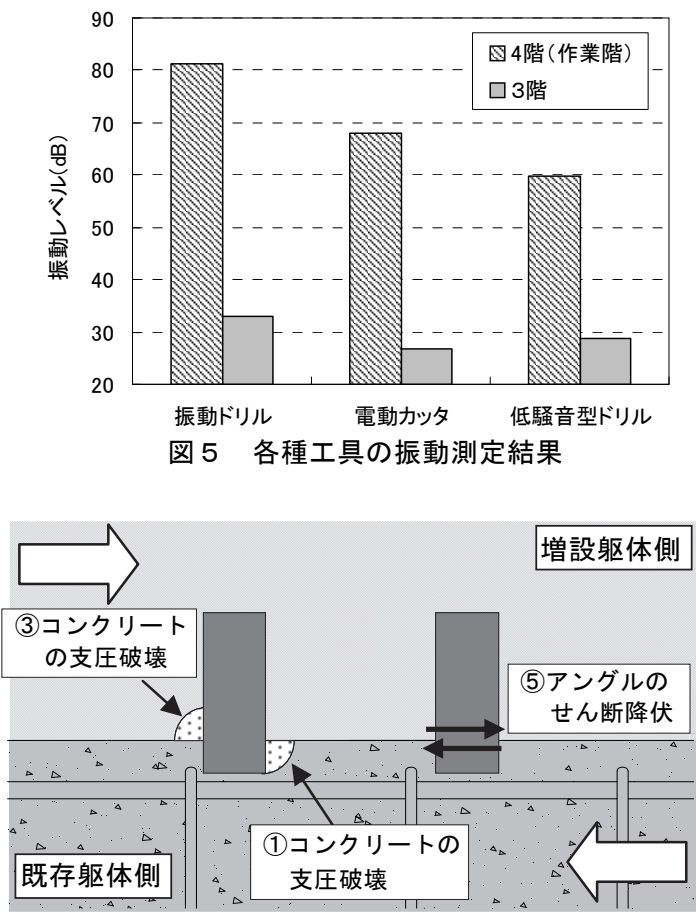

（a）コンクリートの支圧破壊およびアングルのせん断降伏

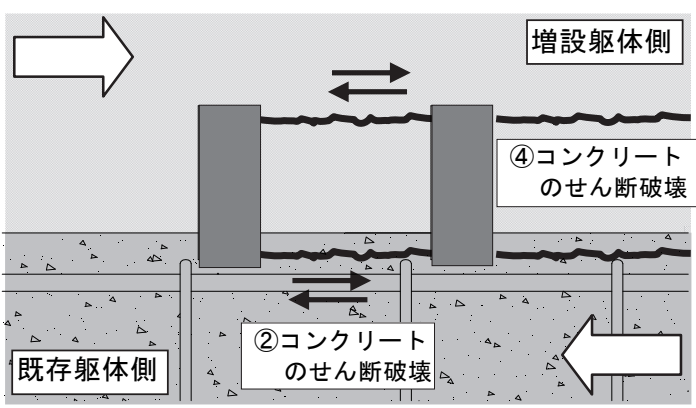

（b）コンクリートのせん断破壊

図 7 接合部の破壊形式 
間接接合部における破壊形式は, 図 7 (a)に示寸(1)および(3)のアン グル周辺のコンクリートが圧壊する支圧破壊, 図 7 (b) に示寸(2)およ び(4)のアングル間のコンクリートがせん断剥離されるせん断破壊, および, 図 7 (a)に示す(5)のアングル周辺のコンクリートは破壊せず, アングルのせん断降伏が先行する 3 つに分類できる。それぞれの破 壊形式の強度をコンクリートの支圧強度, コンクリートのせん断強 度, アングルのせん断強度と呼んでいる。

以下に示寸設計用の接合部のせん断強度は, 接合部の一体性を 確保する観点, および荷重変形関係で相対ずれ変形が $2 \mathrm{~mm}$ 程度で剛 性が低下していることに基づき, 文献 4) と同様に, 相対ずれ変形 $2 \mathrm{~mm}$ における実験荷重をせん断強度として扱い, 破壊形式別に接合 部のせん断強度評価式を提案したものである ${ }^{3)}$ 。

\section{(1) コンクリートの支圧強度}

既存躯体コンクリートの支圧強度 $q_{1}$ および増設躯体コンクリー トの支圧強度 $q_{3}$ は，それぞれ式 (1)，(2)により算定する。

$$
\begin{aligned}
& q_{1}=1.66 \cdot B_{a} \cdot L_{e 1} \cdot\left(B_{a} / t_{1}\right)^{-0.63} \cdot \beta \cdot \sigma_{t 1} \\
& q_{3}=1.66 \cdot B_{a} \cdot L_{e 2} \cdot\left(B_{a} / t_{2}\right)^{-0.63} \cdot \beta \cdot \sigma_{t 2}
\end{aligned}
$$

$$
L_{e 1}=\min \left(1.5 D_{a}, / 3, \quad L_{1}\right), \quad L_{e 2}=1.5 D_{a} / 3
$$$$
\sigma_{t 1}=0.3 \sqrt{F_{c 1}}, \quad \sigma_{t 2}=0.3 \sqrt{F_{c 2}}
$$

ただし， $L_{1}<L_{2}$ および, $L_{2} \geqq 1.5 D_{a}$ とする。

ここで, $t_{1}$ : 既存躯体有効幅, $t_{2}$ : 増設躯体幅, $B_{a}$ : アングルの幅, $D_{a}$ : アングルのせい, $L_{1}$ : 既存躯体側埋込み長さ, $L_{2}$ : 増設部側埋 込み長さ， $F_{c 1}, F_{c 2}$ : それぞれ既存躯体および増設部のコンクリート の圧縮強度, $\beta$ : コンクリート強度係数 (=17.6)である。

\section{(2) コンクリートのせん断強度}

既存躯体コンクリートのせん断強度 $q_{2}$ および増設躯体コンクリ 一トのせん断強度 $q_{4}$ は，それぞれ式 (3)，(4)により算定する。

$q_{2}=0.2 F_{c 1} \cdot A_{s 1}$
$q_{4}=0.2 F_{c 2} \cdot A_{s 2}$

ここで， $A_{s 1}, A_{s 2}$ : それぞれ既存躯体側および増設部におけるアン グル 1 つ当たりのコンクリートのせん断断面積で, 図 8 に示すよう にアングルから $45^{\circ}$ に延びる線で囲まれる部分の面積とする。

\section{(3) アングル材のせん断強度}

アングル材のせん断強度 $q_{5}$ は式(5)により算定する。

$$
q_{5}=\phi_{1} \cdot \sigma_{y a 1} \cdot A_{a 1} / \sqrt{3} \quad[\mathrm{~N}]
$$

ここで, $\phi_{1}$ : 低減係数 $(=0.85), \sigma_{y a 1}$ : アングルの設計用材料強度, $A_{a 1}$ : アングルの断面積。

\section{(4) 実験値と計算値の比較}

破壊形式別に接合部のせん断強度評価式を提案した。接合部の破 壊はいずれかの破壊形式が生じるため, 接合部の耐力はこれらのう ち最小の值となる。図 9 に全試験体の相対ずれ変形 $2 \mathrm{~mm}$ における実 験值 $Q_{2}$ と計算值 $Q_{c a l}$ の比較を示寸。式 (1) (5)の提案式の最小值 による破壊形式は実験結果と一致しており, いずれの破壊形式に対 しても計算值は実験值を安全側に評価することができる。

\section{2 補強架構の加力実験}

本工法で補強した架構の構造性能を確認するために, 約 $1 / 2.2$ の 縮小模型試験体による載荷実験を行った。
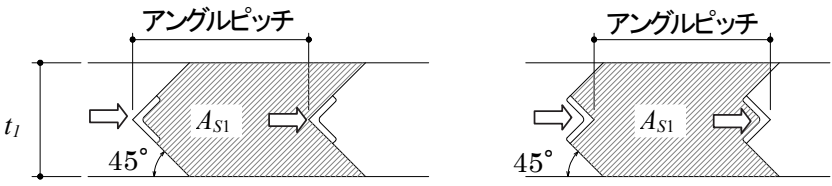

図 8 コンクリートのせん断断面積

\begin{tabular}{|c|c|c|c|c|}
\hline 式験体 & 柱 & 梁 & 補強部材 & 接合面 \\
\hline$\overline{W-1}$ & 主筋: & 主筋: & D6@120(ダブル) & $\mathrm{L}-40 \times 40 \times 3 @ 130$ \\
\hline $\mathrm{W}-2$ & 8-D13 & 12-D13 & D6@80(ダブル) & $L-30 \times 30 \times 3 @ 105$ \\
\hline$W-3$ & 帯筋 & あばら筋 & D6@80(ダブル) & $L-30 \times 30 \times 3 @ 130$ \\
\hline$B-1$ & 2-D4@100 & 2-D4@80 & $\mathrm{H}-100 \times 100 \times 6 \times 8$ & $\mathrm{~L}-30 \times 30 \times 3 @ 120$ \\
\hline
\end{tabular}

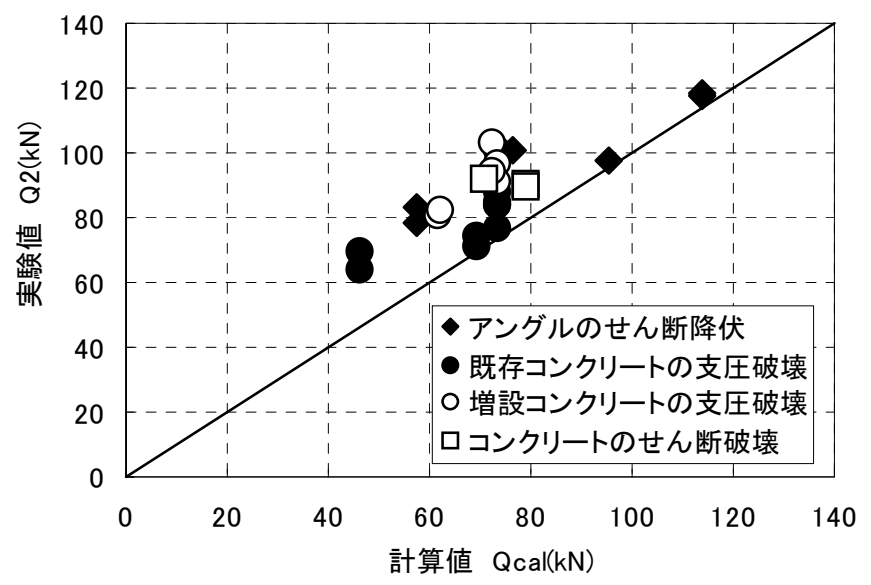

図 9 実験値と計算値の比較

表 1 試験体一覧

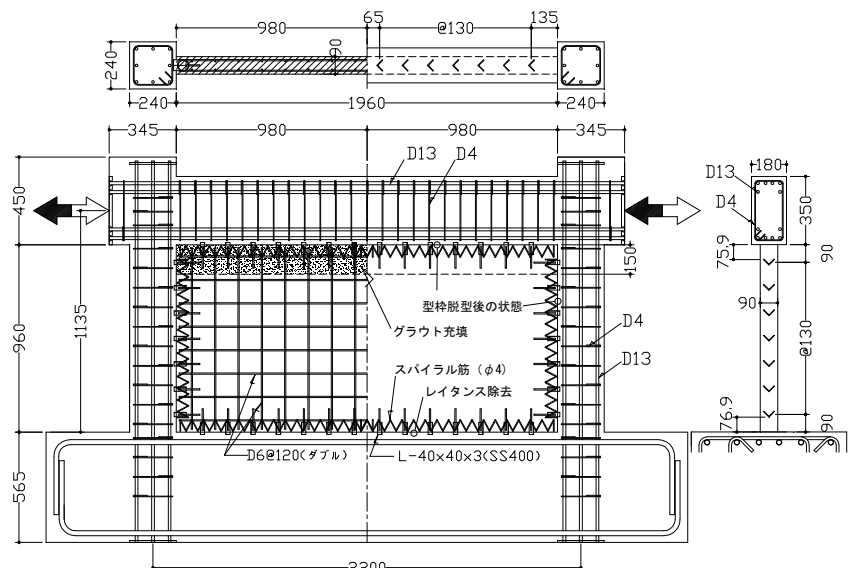

(a) W シリーズ

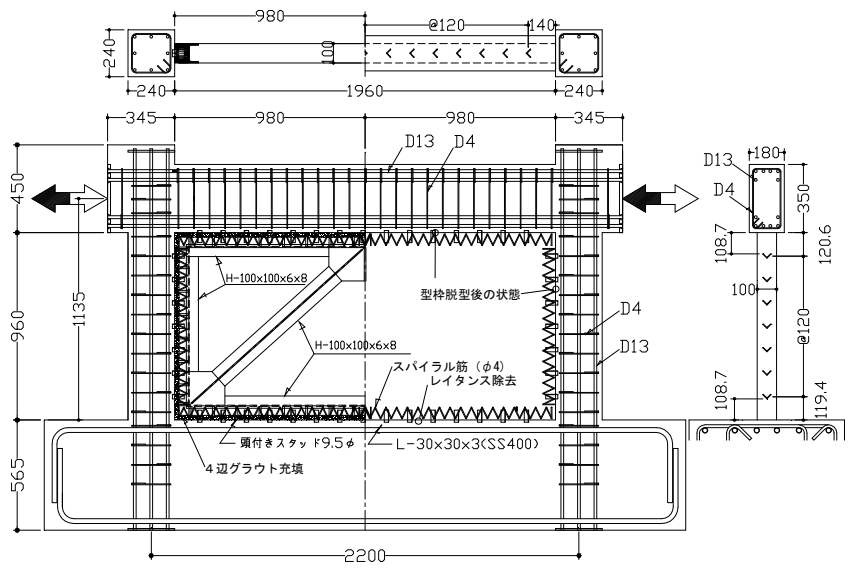

(b) B シリーズ

図 10 試験体形状 


\section{(1) 試験体}

試験体の一覧を表 1 に，その形状を図 10 に示す。試験体は，せ ん断破壊型の柱で構成される 1 層 1 スパンの $\mathrm{R} \mathrm{C}$ 架構を $\mathrm{R} \mathrm{C}$ 増設壁, または枠付き鉄骨ブレースで補強したものである。 R C 増設壁によ り補強したWシリーズが 3 体, 枠付き鉄骨ブレースとして $\mathrm{H}$ 形鋼を K型に配置した B シリーズが 1 体の合計 4 体である。

試験体は接合部のせん断強度と補強部材の強度比により，破壊モ ードが異なるように接合部の耐力を実験要因とした。W-1 は増設部 破壞が先行するように，また W-2, W-3 は接合部破壊が先行するよう に接合部の強度を決定した。B-1 は接合部破壊が先行する試験体と した。間接接合部のアングルは一辺が $30 \mathrm{~mm}$ または $40 \mathrm{~mm}$ の等辺山形 鋼を使用し,身体一の埋め込み長さはアングルせい $D_{a}$ の $1 / 2$ とした。 前述したように接合部の破壊型式にはコンクリートの支圧破壊, せん断破壊, およびアングルのせん断降伏がある。試験体の接合部 強度は全てアングルのせん断降伏で耐力が決まるようにアングル間 隔を設定した。アングルの取り付け方向は，柱面では上向きに開い た形に，梁では柱側に開いた形となるように，梁中央で向きを変え て取り付けた。なお，Wシリーズのアングルには，増設壁の定着筋 として接合面から鉄筋端部までを $20 \mathrm{~d}$ の長さとなるようにD6の鉄筋 をフレア溶接で取け付けている。いずれの試験体も間接接合部には 割裂防止筋として，4 ピッチを B-1 では $55 \mathrm{~mm}$, 他の試験体は $60 \mathrm{~mm}$ のスパイラル筋として 配置した。また， R C 架構の打継ぎ面の目荒らしは施していない。

表 2 に試験体に使用したコンクリートの材料試験結果を, 表 3 に 鋼材の材料試験結果を示す。試験体に使用したコンクリートは，柱， 梁が Fc13.5, 増設壁が Fc21, 充填モルタルが 49.6〜79.2 N/mm² と した。鉄筋はSD295を，鋼材はSS400 を使用した。

加力は両側柱に長期軸力を想定した軸力 (コンクリート強度の 0.15 倍)を作用させた状態で, 梁両側の加力スタブにより押し引き 載荷を行った。加力の制御は梁中心位置での水平変位を制御変位と $し て$, 層間変形角 $R$ (梁中央の水平変形をスタブからの加力点高さ $1135 \mathrm{~mm}$ で除した值)を漸増させながら正負繰り返し載荷を行った。 載荷履歴は層間変形角 $R=1 / 4000,1 / 2000 \mathrm{rad}$. で正負 1 サイクルの載 荷を行った後， $R=1 / 1000,1 / 500,1 / 250,1 / 150,1 / 100 \mathrm{rad}$. で正負 2 サイクル， $R= \pm 1 / 66,1 / 50 \mathrm{rad} . の 1$ サイクルの載荷を行った。

\section{(2) 実験結果}

試験体の荷重変形関係を図 11 に, 加力終了時の代表的な破壊状況 を図 12 に示す。

W-1 は，層間変形角 $R=6.5 / 1000 \mathrm{rad}$. で圧縮柱にせん断ひび割れが 発生し， $R=1 / 150 \mathrm{rad}$. で最大耐力に達した。破壊型式は, 明確な破 壊には至ってないが壁筋の一部が降伏した後に, 引張柱のパンチン グシア破壞，圧縮柱のせん断破壊を伴った接合部破壊となった。な お，壁筋の降伏を確認できていることより，破壊形式は増設部破壊 として扱う。

W-2 は, 層間変形角 $R=-4 / 1000 \mathrm{rad}$. で圧縮柱にせん断ひび割れが 発生し， $R=3.7 / 1000 \mathrm{rad}$. で最大耐力に達した。破壊形式は，引張柱 のパンチングシア破壊，圧縮柱のせん断破壊を伴った接合部破壊で ある。なお，壁筋は降伏していない。

W-3 は，層間変形角 $R=5.1 / 1000 \mathrm{rad}$. で圧縮柱にせん断ひび割れが 発生し, $R=1 / 250 \mathrm{rad}$. で最大耐力に達した。破壊形式は, 引張柱の
表 2 コンクリートの材料試験結果

\begin{tabular}{|c|c|c|c|}
\hline \multirow{3}{*}{ 試験体 } & \multicolumn{2}{|c|}{ コンクリート圧縮強度 } & \multirow{2}{*}{$\begin{array}{l}\text { モルタル } \\
\text { 圧縮強度 }\end{array}$} \\
\hline & 柱·梁 & 増設壁 & \\
\hline & $\left(\mathrm{N} / \mathrm{mm}^{2}\right)$ & $\left(\mathrm{N} / \mathrm{mm}^{2}\right)$ & $\left(\mathrm{N} / \mathrm{mm}^{2}\right)$ \\
\hline$W-1$ & 18.7 & 29 & 71.6 \\
\hline$W-2$ & 24.9 & 27.9 & 49.6 \\
\hline$w-3$ & 24.7 & 30.5 & 79.2 \\
\hline$B-1$ & 18.7 & - & 58.4 \\
\hline
\end{tabular}

表 3 鋼材の材料試験結果

\begin{tabular}{|c|c|c||c|c|c|}
\hline 種類 & 使用部位 & $\begin{array}{c}\text { 降伏強度 } \\
\left(\mathrm{N} / \mathrm{mm}^{2}\right)\end{array}$ & 種類 & 寸法 & $\begin{array}{c}\text { 降伏強度 } \\
\left(\mathrm{N} / \mathrm{mm}^{2}\right)\end{array}$ \\
\hline D13 (SD295) & 柱・梁主筋 & 362 & アングル & $30 \times 30 \times 3$ & 387 \\
\cline { 5 - 6 } D4 (SD295) & せん断補強筋 & 378 & H形鋼フランジ & $\mathrm{t}=8$ & 352 \\
\hline $\mathrm{D6}$ (SD295) & $\begin{array}{c}\text { 譬筋 } \\
(\mathrm{W}-1, \mathrm{~W}-2)\end{array}$ & 358 & H形鋼ウェブ & $\mathrm{t}=6$ & 350 \\
\hline $\mathrm{D6}$ (SD295) & $\begin{array}{c}\text { 壁筋 } \\
(\mathrm{W}-3)\end{array}$ & 361 & 頭付きスタッド & $9.5 \phi$ & 367 \\
\hline
\end{tabular}

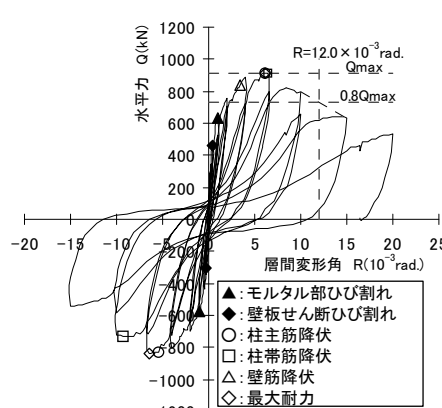

(a) $\mathrm{W}-1$

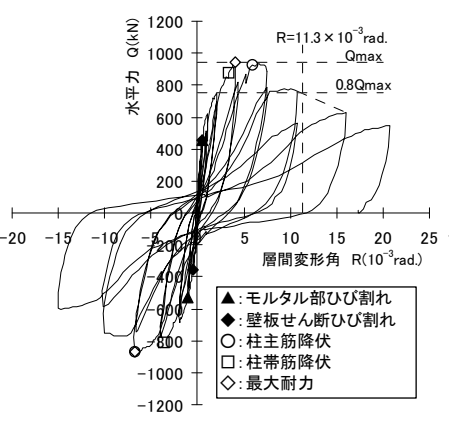

(c) $\mathrm{W}-3$

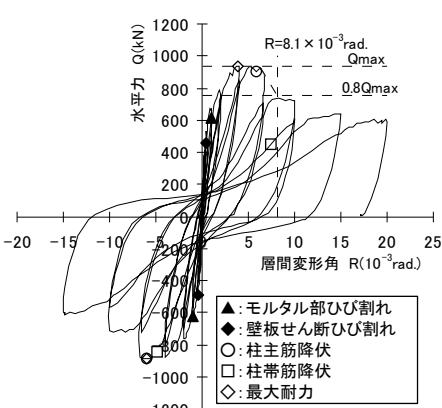

(b) W-2

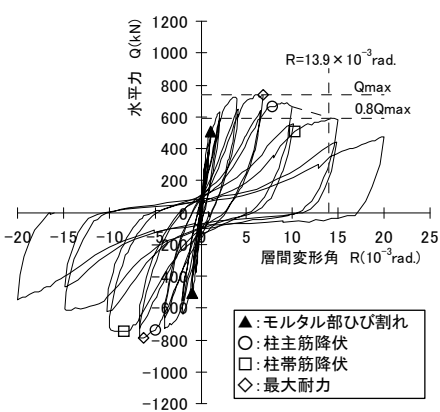

(d) B-1
図 11 荷重変形関係

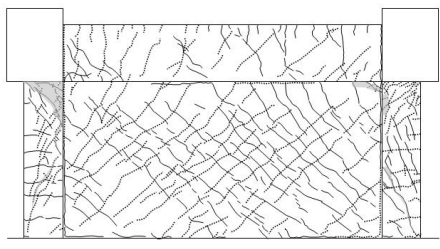

(a) $\mathrm{W}-2$

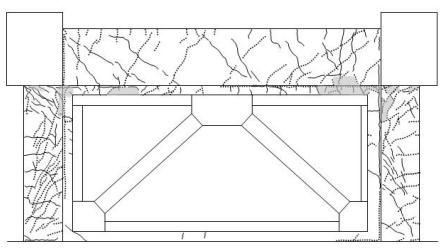

(b) B-1
図 12 最終ひび割れ状況

パンチングシア破壊，圧縮柱のせん断破壊を伴った接合部破壊であ る。なお，壁筋は降伏していない。

B-1 は, 層間変形角 $R=2.0 / 1000 \mathrm{rad}$. で引張柱の柱頭にパンチング シア状のひび割れが発生し， $R=1 / 250 \mathrm{rad}$. で圧縮柱にせん断ひび割 れが発生した。その後, $R=1 / 50 \mathrm{rad}$. まで加力を進めると, せん断ひ び割れ幅の拡大，圧縮側柱の柱梁接合部付近の充填モルタルの圧壊 などが生じたが，柱の軸力保持能力は保持していた。なお，ブレー ス材の降伏は生じていない。破壊形式は, 引張柱のパンチングシア 
破壊，圧縮柱のせん断破壊を伴った接合部破壊である。

各試験体の荷重変形関係を比較する。試験体の破壊形式が増設部 破壊または接合部破壊を示したために, いずれの試験体も層間変形 角 $R=1 / 250$ から $1 / 150 \mathrm{rad}$. 程度で最大耐力に達した後に, 耐力低下 が生じ始めている。増設壁試験体において, 間接接合部強度に関わ りなく初期剛性は同程度となっている。また, W-2 と W-3 は接合部 の強度が異なるが，荷重変形関係に明確な差は観察されなかった。 補強部材が異なる W-1 と B-1 を比較すると補強部材が増設壁である W-1 の方が，剛性が高くなっている。両試験体とも脆性的は破壊形 式であるため, 最大耐力以降の荷重低下はほぼ同程度である。

\section{4. 試験体の水平最大耐力の評価法と勒性指標}

\section{1 補強架構の終局せん断耐力}

補強架構の終局せん断強度は文献 5) および文献 6) に準じて増設 部破壊，接合部破壊および曲げ破壊の各強度のうち最小值とする。 本工法により補強された骨組の終局せん断耐力は, 間接接合部の強 度により, 図 13 に示寸タイプ I , およびタイプII の 2 つの破壊形式 に分類される。

タイプ I は間接接合部のせん断強度が十分に大きく, 補強骨組の 終局せん断耐力が補強部材の破壊によって決まり, 在来工法と同様 に一体打ち耐震壁または鉄骨ブレースの性状に支配される破壊形式 である。これに対して，タイプIIは間接接合部のせん断強度が相対 的に小さく, 間接接合部にずれ変形が生じて, 増設部材の破壊より も間接接合部が先行してせん断強度に達した後, これらの耐力を維 持しつつ, 既存の引張柱のパンチングシア破壊および圧縮柱のせん 断あるいは曲げ破壊が生じ, 耐力が低下寸る破壊形式である。

\section{(1) R C 増設壁補強}

$\mathrm{R} C$ 増設壁により補強された補強骨組の終局せん断耐力 $Q_{s u}$ は, 以下の 1 ）から 3 ）に示寸破壊形式がタイプI の一体打ち壁として のせん断耐力 $Q_{s u 1}$, または増設壁の内法部分のせん断破壊型のせん 断耐力 $Q_{s u 2}$, およびタイプII の接合部破壊型のせん断耐力 $Q_{s u 3}$ のう ち最小值とする。

\section{1)一体打ち壁としてのせん断耐力}

一体打ち壁としてのせん断終局耐力 $Q_{s u 1}$ は次式 ${ }^{5)}$ による。

$$
Q_{s u 1}=\left\{\frac{0.053 \cdot p_{t e}^{0.23}\left(18+F_{c 1}\right)}{M /(Q \cdot \ell)+0.12}+0.85 \sqrt{p_{s e} \cdot \sigma_{y}}+0.1 \sigma_{0 e}\right\} b_{e} \cdot j_{e}
$$

\section{2) 増設壁の内法部分のせん断破壊型のせん断耐力}

増設壁の内法部分のせん断破壊型の破壊モードを示寸場合の補 強架構の終局せん断耐力 $Q_{s u 2}$ は次式による。 ${ }_{w} Q_{s u}{ }^{\prime}$ は増設壁板のせ 几断耐力を示し, 文献 6)による。

$$
Q_{s u 2}={ }_{w} Q_{s u}{ }^{1}+2 \alpha \cdot Q_{c 2}
$$

ここで， $Q_{c 2}$ は圧縮側柱の終局耐力， $\alpha$ は変形状態を考慮した低減 係数で, 柱せん断破壊型では 1.0 , 柱曲げ破壊型では 0.7 である。

\section{3) 接合部破壊型のせん断耐力}

接合部破壊型の破壊モードを示す場合の補強架構の終局せん断耐 力 $Q_{s u 3}$ は次式による。なお, 接合部のせん断耐力 $Q_{j u}$ は式(1)〜 (5) に よる。 ${ }_{p} Q_{c}$ は柱のパンチングシア耐力を示し, 文献 6)による。

$Q_{s u 3}=Q_{j u}+{ }_{p} Q_{c}+\alpha \cdot Q_{c 2}$

(2) 枠付き鉄骨ブレース補強
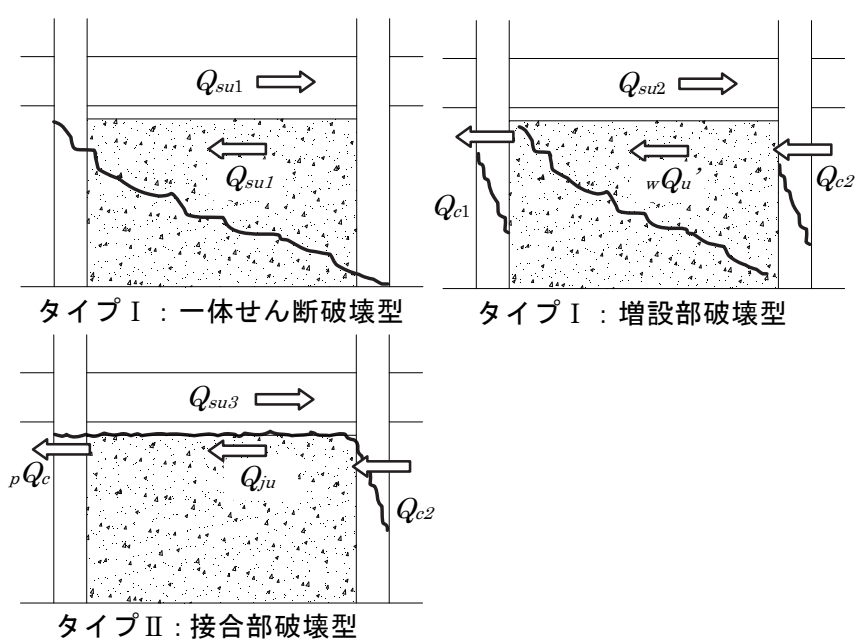

タイプ I：増設部破壊型

（a） RC 増設壁補強工法

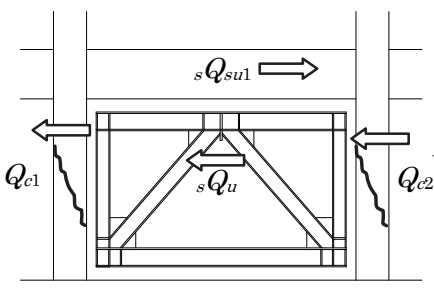

タイプ I：増設部破壊型

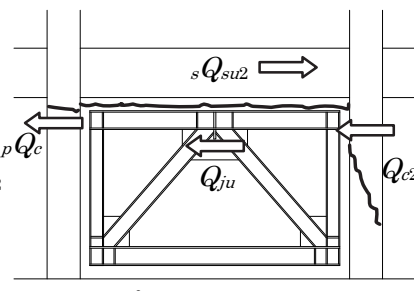

タイプI：接合部破壊型 （b）枠付き鉄骨ブレース補強工法

図 13 補強架構の破壊形式

枠付き鉄骨ブレースで補強された補強骨組の終局せん断耐力 ${ }_{s} Q_{s u}$ は, 以下の 1 ) から 2 ) のブレース破壊先行型の終局せん断耐力 ${ }_{s} Q_{s u 1}$, 接合部破壊先行型の終局せん断耐力 ${ }_{s} Q_{s u 2}$ のうち最小值とする。

\section{1) ブレース破壊型のせん断耐力}

鉄骨ブレースが引張降伏あるいは座屈し，柱が曲げ破壊またはせ ん断破壊する場合の終局せん断耐力 ${ }_{s} Q_{s u 1}$ は次式による。

$$
{ }_{s} Q_{s u 1}=\alpha\left(Q_{c 1}+Q_{c 2}\right)+{ }_{s} Q_{u}
$$

ここで, ${ }_{s} Q_{u}$ は鉄骨ブレースの水平せん断耐力, $Q_{c 1}$ は引張側柱の 終局耐力を示す。

\section{2)接合部破壊型のせん断耐力}

接合部が破壊し, 引張側柱頭部がパンチングシア破壊し, 圧縮側 柱が曲げ破壊またはせん断破壊する場合の終局せん断耐力 ${ }_{s} Q_{s u 2}$ は 次式による。

$$
{ }_{s} Q_{s u 2}=Q_{j u}+{ }_{p} Q_{c}+\alpha \cdot Q_{c 2}
$$

\section{(3) 補強架構の曲げ耐力}

補強架構の全体曲げ耐力は，増設された R C 増設壁の壁筋，ある いはブレース架構の寄与分を無視し, 既存柱の引張降伏耐力または, 圧縮降伏耐力のいずれか小さい值により算定する。

$$
\begin{aligned}
Q_{m u}= & M_{u} / h \\
M_{u}= & \min \left(T_{u}, C_{u}\right) \cdot l \\
& T_{u}=N_{1}+a_{g}{ }_{c} \sigma_{y} \\
& C_{u}=0.8\left(b \cdot D \cdot F_{c 1}+a_{g}{ }_{c} \sigma_{y}\right)-N_{2}>0
\end{aligned}
$$

ここで, $N_{1}, N_{2}$ : それぞれ引張側, 圧縮側の長期軸方向力, $b:$ 柱 幅, $D:$ 柱せい, $h$ : 反曲点高さ, $l:$ 引張側柱および圧縮側柱の中 心間距離, ${ }_{c} \sigma_{y}$ : 柱主筋または柱鉄骨の設計用降伏点強度, $F_{c 1}$ : 既存 柱のコンクリートの設計用圧縮強度, $a_{g}$ : 柱主筋および柱鉄骨の全 
断面積。

\section{(4) 実験值と計算値の比較}

試験体の最大耐力と計算值の比較を表 4 および図 14 に示す。実 験值と計算值との比が $1.26 \sim 1.48$ となり，いずれの試験体において も提案式は耐力を十分安全側に評価することができる。また, 計算 值による破壊形式と一致している。

表 4 実験値と計算値の比較

\begin{tabular}{|c|c|c|c|c|c|}
\hline \multirow{2}{*}{\multicolumn{2}{|c|}{ 試験体 }} & \multicolumn{3}{|c|}{ RC増設壁試験体 } & \multirow{2}{*}{$\begin{array}{c}\text { 枠付き鉄骨ブ } \\
\text { レース試験体 }\end{array}$} \\
\hline & & $\bar{W}-1$ & $\mathrm{~W}-2$ & W-3 & \\
\hline \multicolumn{2}{|c|}{ 最大耐力 (実験値,kN) } & 913.3 & 939.4 & 940.9 & 790.3 \\
\hline \multirow{3}{*}{$\begin{array}{c}\text { 増設部破壊 } \\
(\mathrm{kN})\end{array}$} & 式(6) & 669.9 & 803.6 & 801.3 & - \\
\hline & 式(9) & - & - & - & 1185.0 \\
\hline & 式(7) & 616.9 & 753.5 & 745.5 & - \\
\hline \multirow{2}{*}{$\begin{array}{c}\text { 接合部破壊 } \\
(\mathrm{kN})\end{array}$} & 式(8) & 706.0 & 746.6 & 648.3 & - \\
\hline & 式(10) & - & - & - & 615.4 \\
\hline \multicolumn{2}{|c|}{ 曲げ破壊(kN) } & 1026.1 & 1129.9 & 1126.6 & 1047.8 \\
\hline \multicolumn{2}{|c|}{ 計算値(最小値、 kN) } & 616.9 & 746.6 & 648.3 & 615.4 \\
\hline \multicolumn{2}{|c|}{ 計算値による破壊形式 } & 増設部破壊 & 接合部破壊 & 接合部破壊 & 接合部破壊 \\
\hline \multicolumn{2}{|c|}{ 実験値／計算值 } & 1.48 & 1.26 & 1.45 & 1.28 \\
\hline
\end{tabular}

\section{2 靬性指標 $F$ 值}

柱せん断破壊型 R C 架構 ( $\mathrm{F}=1.0)$ の試験体を本工法を用いた R C 増設壁または枠付き鉄骨ブレースで補強した試験体の荷重変形関係 を図 15 に示す。図中には文献 5) で示されている式(12)による F 值 を併記する。

$$
\begin{aligned}
& F=\sqrt{2 \mu-1} /\{0.75(1+0.05 \mu)\} \\
& \mu=R_{u} / R_{y} \\
& \text { ここで, } R_{u} \text { : 限界部材角, } R_{y}=1 / 150 。
\end{aligned}
$$

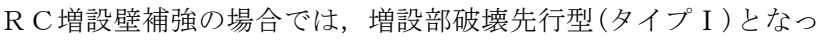
た W-1, 接合部破壊先行型 (タイプII ) の W-2 および W-3 試験体の最 大耐力は，W-1 で層間変形角 $R=1 / 150 \mathrm{rad} ., W-2, W-3$ では層間変形 角 $R=1 / 250 \mathrm{rad}$. で生じている。なお, W-1 の最大耐力は $R=1 / 250 \mathrm{rad}$. 時耐力を $R=1 / 150 \mathrm{rad}$. 時の耐力が若干上回った程度である。以上の ことより，本工法で補強した架構の勒性指標 $\mathrm{F}$ 值は， R C 造増設壁 補強工法の場合, 増設部破壊先行型 (タイプ I ), 接合部破壊先行型 (タイプ II ) ともに F = 1.0 を確保できている。また，枠付き鉄骨ブレ 一ス補強の場合, 最大耐力は $R=1 / 150 \mathrm{rad}$. 程度で生じ, その後の耐 力低下は穏やかで層間変形角 $R=1 / 100 \mathrm{rad}$. においても最大耐力の 80\%の耐力を保持している。

以上のことより, 本工法で補強した架構の勒性指標 $\mathrm{F}$ 值は, R C 増設壁補強工法における増設部破壊先行型および接合部破壊先行型 では $\mathrm{F}=1.0$ 程度の変形性能を，また，枠付き鉄骨ブレース補強にお ける柱のパンチングシアと接合部の破壊型では $\mathrm{F}=1.27$ 程度の変形 性能を有していると考えられる。

\section{5. まとめ}

施工時の振動騒音を在来工法に比べて低減する補強工法を考案 し，各種工具の騒音振動測定および 1 層 1 スパン $\mathrm{R} \mathrm{C}$ 架構の加力実 験を実施し, 得られた騷音振動のレベル, 最大耐力, 変形性能等の 実験結果を検討した結果，以下のことが明らかになった。

(1) あと施工アンカーの施工で使用される振動ドリルに比べて, 本工 法では騒音振動が低減できることが確認できた。

(2) 最大耐力は提案式による計算值を上回り, 提案式は本工法による
補強架構の耐力を適切に評価できる。

（3）靭性指標 $\mathrm{F}$ 值は， R C 増設壁補強工法における増設部破壊型およ び接合部破壞型では $\mathrm{F}=1.0$, また，枠付き鉄骨ブレース補強工法 の接合部破壊型では $\mathrm{F}=1.27$ であることを確認した。

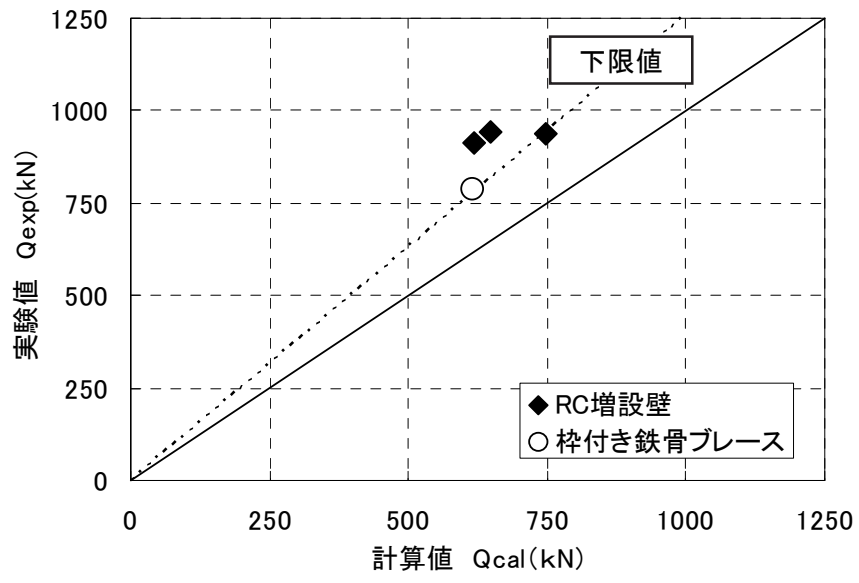

図 14 実験值と計算値の比較

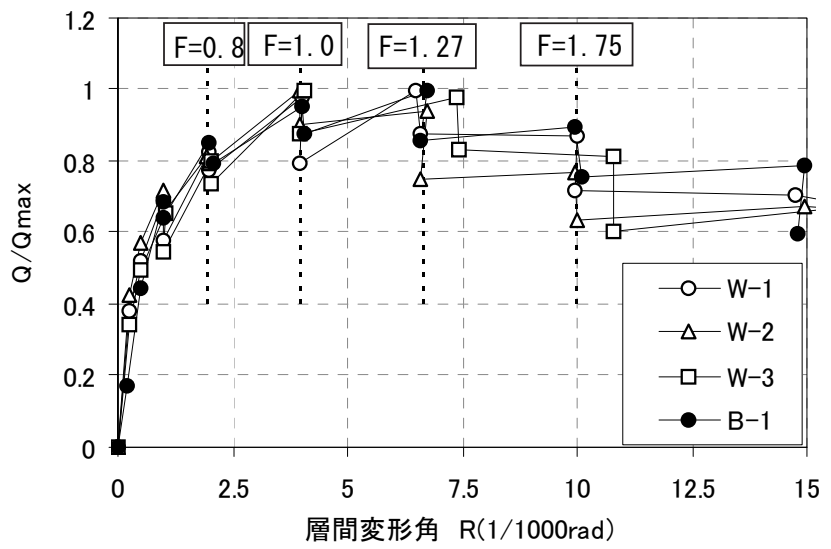

図 15 荷重変形関係の包絡線

\section{参考文献}

1) 例えば毛井崇博, 宮内靖昌 : 接着接合された鉄骨ブレース補強骨組の力学, 日本建築学会構造系論文集 第 539 号, 103-109, 2001.1

2) 荒井豊人,ほか 8 名 : 鋼管をコッターとして用いた耐震補強工法の実験的研 究（その 2. 耐震壁実験）, 日本建築学会大会梗概集, 構造IV, pp. 1193-1194, 2001. 7

3)岩川浩二,ほか 3 名 : 在来型耐震補強工法の改良に関する実験的研究（その 1 2) , 日本建築学会大会梗概集, 構造IV,pp. 585-588, 2010.9

4) 日本建築防災協会 : 既存鉄筋コンクリート造建物の「外側而震改修マニュ アルー枠付き鉄骨ブレースによる補強一」,2002.9

5）日本建築防災協会 : 2001 年改訂版 既存鉄筋コンクリート造建築物の耐震 診断基準 ・ 同解説, 2001. 10

6) 日本建築防災協会 : 2001 年改訂版 既存鉄筋コンクリート造建築物の耐震 改修設計指針・同解説, 2001.10

7) 日本建築総合試験所 : 建築技術性能証明 評価概要報告書 Trench-A 工法アングルをシアキーとして用いる耐震補強工法-, 2011.6

[2011 年 6 月 20 日原稿受理 2011 年 9 月 15 日採用決定］ 